\title{
Vitamin and mineral needs during the oral contraceptive therapy: a systematic review
}

\author{
Giulia Dante $^{1}$, Alberto Vaiarelli ${ }^{2}$, Fabio Facchinetti ${ }^{1}$ * \\ ${ }^{1}$ Department of Mother-Infant, University of Modena and Reggio Emilia, Italy \\ ${ }^{2}$ Department of Reproductive Medicine, Policlinico Universitario di Messina, Messina, Italy
}

Received: 17 November 2013

Accepted: 16 December 2013

\section{*Correspondence:}

Dr. Fabio Facchinetti,

E-mail: facchi@unimore.it

(c) 2014 Dante $\mathrm{G}$ et al. This is an open-access article distributed under the terms of the Creative Commons Attribution Non-Commercial License, which permits unrestricted non-commercial use, distribution, and reproduction in any medium, provided the original work is properly cited.

\section{ABSTRACT}

Objectives: There is growing evidence that women using OCs change in serum trace elements and vitamins. Nowadays, in many cases, side effects associated with low levels of micronutrients are not considered during oral contraceptives (OCs) therapy. This review aims at checking the present literature in order to verify the evidences. Our purpose is to underline this aspect contributing to improve the therapeutic approach with OCs.

Methods: Systematic literature search was performed in electronic databases, covering the period from January 1967 to January 2012.

Results: Ninety-five articles were located; a cross sectional randomized and three RCTs studies were considered eligible.

Conclusions: A decrease in the serum concentrations of zinc, selenium, phosphorus and magnesium have been reported in OC users. Such reductions were proportional to the duration of contraceptive use. These reductions may imply a reduction in the probability of having a pregnancy and/or an increase of serious illness for the unborn. In this regard, a supplementation with the above compounds could be useful in OC users, namely for reducing side effects.

Keywords: Oral contraceptive pill, Nutritional requirements, Vitamins deficiency, Micronutrients deficiency, Serum trace elements

\section{INTRODUCTION}

In recent years there has been growing interest concerning alterations of metabolic processes and trace element profiles associated with the use of oral contraceptives (OC). Such changes are driven by genetic predisposition as well as environmental factors, changes in lifestyle, dietary habits and active ingredients of hormonal compounds. Indeed, several reviews indicate that $\mathrm{OC}$ administration affects metabolism of vitamins and minerals. ${ }^{1-5}$

Some of these micronutrients are co-factors and/or coenzymes involved in important metabolic pathways. Changes in their tissue level or bioavailability might play a significant role in health risk and might be involved in the pathogenesis of some disorders. ${ }^{6}$

Literature data report the administration of various combined estrogen-progestin pills is able to change micronutrient levels. Unfortunately, it is not always clear which component of the $\mathrm{OC}$ is responsible for the observed changes. Even nutritional experts' opinions differ in the interpretation of the biochemical results and the uncontrolled administration of dietary supplements to OC users makes comprehension of the effects on the women's health more difficult. ${ }^{7,8}$

The present systematic review aims at providing a comprehensive view of the literature evidence about the changes of nutritional needs in women who use OCs. 


\section{MATERIALS AND METHODS}

Systematic literature searches were performed in April 2012 using the following electronic databases: Medline, Amed and The Cochrane Library. We performed a search over the period from January 1967 to January 2012; a cross sectional randomized and three RCTs studies were included.

The search terms were: 'oral contraceptives', 'homocysteine', 'micronutrients', 'serum trace elements', 'vitamins', 'minerals', 'vitamin A', 'vitamin E', 'vitamin C', 'vitamin $\mathrm{B}_{6}$ ', 'vitamin $\mathrm{B}_{12}$ ', 'iron', 'copper', 'zinc', selenium', 'magnesium', calcium', 'folic acid', 'folate status'.

The search was limited to articles published in English and easily retrievable via the home library.

Further relevant papers were located by hand-searching the reference lists of recent trials. We attempted to obtain hard copies of all the papers listed through our own university library or by interlibrary loans. Only human studies were included while in vitro investigations were excluded.

This systematic review was written based on the Quorum Statement guidelines. ${ }^{9}$

\section{RESULTS}

Decision tree is reported in Figure 1.

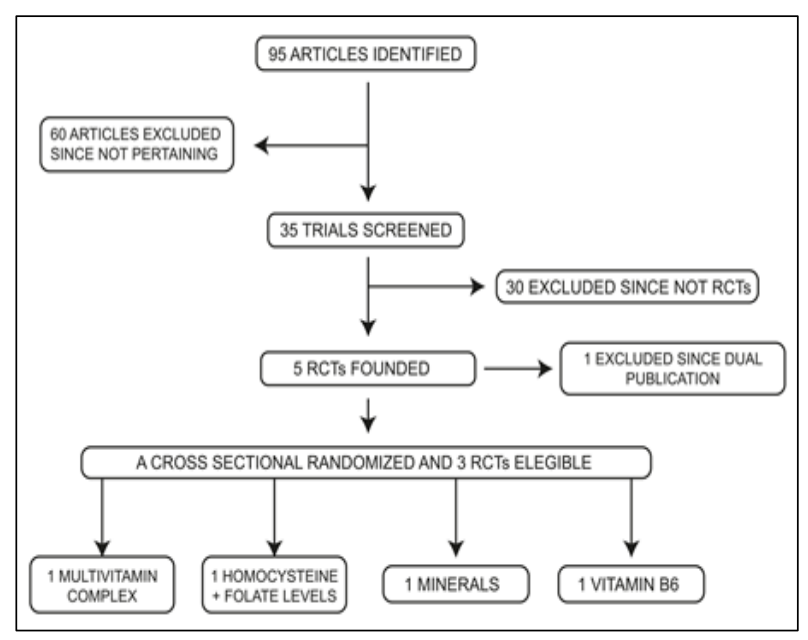

Figure 1: Schematic representation of studies considered.

Out of the 95 studies that were identified, 60 were excluded because they did not evaluate vitamin or mineral changes in $\mathrm{OC}$ users.

The remnant 35 studies were screened, 30 of them being excluded because they were not designed as RCTs while 1 was a duplicate publication. This process allowed a cross sectional randomized and 3 RCTs studies which were eligible for this review. ${ }^{10-13}$

Two of them pertain the effects of either a daily multivitamin complex ${ }^{10}$ or a vitamin B6 supplement ${ }^{13}$ on the reduction of OC side effects. Two other trials evaluated the effects of $\mathrm{OC}$ use on either serum trace elements, calcium and phosphorus levels ${ }^{11}$ or on the folate status and homocysteine levels. ${ }^{12}$

Inclusion and exclusion criteria as well the main outcome measures for all those studies are described in Table 1.

The study of Bart et al. ${ }^{12}$ was a randomized double blind trial which investigated the change of folate in red blood cells (RBC) and plasma, and homocysteine levels during a 24-week oral administration of ethinyl estradiol (EE) 20 $\mathrm{mcg} / \mathrm{drsp} 3 \mathrm{mg} / \mathrm{levomefolate}$ calcium $0.451 \mathrm{mg}$ compared with an established OC containing EE $20 \mathrm{mcg} / \mathrm{drsp} 3 \mathrm{mg}$. For each 28-day treatment cycle, healthy women seeking contraception received EE/drsp/levomefolate calcium for 24 days followed by levomefolate calcium $0.451 \mathrm{mg}$ alone for 4 days or EE/drsp for 24 days followed by placebo for 4 days. Compliance was good in both groups.

Three hundred seventy-nine women were randomized (EE/drsp/levomefolate calcium, $\mathrm{N}=285 ; \mathrm{EE} / \mathrm{drsp}, \mathrm{N}=94$ ) and received at least one dose of study treatment. During the study there was a drop out of 100 women who prematurely left the treatment. However, assessment of the outcomes was performed with both per protocol set (PPS) and full-analysis set (FAS).

Primary outcome of the study was the evaluation of RBC folate and plasma folate levels at week 24. Mean RBC folate levels in PPS increased from $990 \pm 390 \mathrm{nmol} / \mathrm{L}$ to $1406 \pm 440 \mathrm{nmol} / \mathrm{L}$ at week 24 in subjects who received EE/drsp/levomefolate calcium while no particular changes were observed in the EE/drsp group. Similarly, a statistically significant increase between baseline and week 24 was observed for plasma folate in $\mathrm{EE} / \mathrm{drsp} / \mathrm{levomefolate}$ calcium group, whereas only a small variation was observed with the EE/drsp. Within the FAS, both treatment groups provided RBC and plasma folate levels comparable to those of the PPS at baseline and at week 24 .

Secondary outcomes were RBC folate and plasma folate at weeks 4, 8, 12, 16 and 20, plasma homocysteine levels at weeks 4, 8, 12, 16, 20 and 24 and evaluation of NTD risk reduction based on the changes of $\mathrm{RBC}$ folate levels.

Within the PPS, subjects who received the $\mathrm{EE} / \mathrm{drsp} /$ levomefolate calcium reported an increase of RBC folate levels at all time points. Furthermore, after 4 weeks of $\mathrm{EE} / \mathrm{drsp} /$ levomefolate calcium treatment, plasma homocysteine levels decreased to $6.9 \pm 1.1 \mathrm{mcg} / \mathrm{L}$ at week 8 , while no reduction was observed in the EE/drsp group. Similar results were obtained within the FAS. 
Table 1: Features of randomized controlled trials.

\begin{tabular}{|c|c|c|c|c|c|c|c|}
\hline Ref. & $\begin{array}{l}\text { Study } \\
\text { design }\end{array}$ & $\begin{array}{l}\text { Treatment/ } \\
\text { Dose } \\
\text { Duration }\end{array}$ & $\mathbf{N}^{\circ}$ of subjects & $\begin{array}{l}\text { Inclusion } \\
\text { criteria }\end{array}$ & $\begin{array}{l}\text { Exclusion } \\
\text { criteria }\end{array}$ & $\begin{array}{l}\text { Assessment of } \\
\text { the response }\end{array}$ & Results \\
\hline (11) & $\begin{array}{l}\text { Cross- } \\
\text { sectiona } \\
1 \\
\text { randomi } \\
\text { zed }\end{array}$ & $\begin{array}{l}\text { Different } \\
\text { hormonal } \\
\text { contracepti } \\
\text { ves for at } \\
\text { least } 12 \\
\text { months }\end{array}$ & $\begin{array}{l}\mathrm{N}^{\circ}=100 \\
\text { Treatment: } \\
\text { - OC: } 50 \\
\text { - injectables: } 25 \\
\text { - IUD: } 25 \\
\text { Controls: } \\
50 \text { age-matched } \\
\text { non } \\
\text { contraceptive } \\
\text { users }\end{array}$ & $\begin{array}{l}\text { Women } \\
\text { aged } 18-40 \\
\text { years, on } \\
\text { different } \\
\text { OC for at } \\
\text { least12 } \\
\text { months }\end{array}$ & $\begin{array}{l}\text { Pregnancy } \\
\text { or lactation }\end{array}$ & $\begin{array}{l}\text { Serum was } \\
\text { analysed using } \\
\text { atomic } \\
\text { absorption } \\
\text { spectrophotomet } \\
\text { er for zinc, } \\
\text { copper, } \\
\text { manganese, } \\
\text { iron, selenium, } \\
\text { cadmium, lead } \\
\text { and magnesium } \\
\text { while } \\
\text { colorimetric } \\
\text { method was } \\
\text { used for } \\
\text { phosphorus and } \\
\text { calcium. BMI } \\
\text { was calculated } \\
\text { as weight in } \\
\text { kg/h in meter } \\
\text { squared. }\end{array}$ & $\begin{array}{l}\text { The mean serum } \\
\mathrm{Zn}, \mathrm{Se}, \mathrm{P}, \mathrm{Mg}, \\
\text { levels obtained } \\
\text { from subjects on } \\
\text { contraceptives } \\
\text { were significantly } \\
\text { lower than those } \\
\text { of the control } \\
\text { group. The mean } \\
\text { serum } \mathrm{Cu}, \mathrm{Fe}, \mathrm{Ca} \\
\text { and Cd levels were } \\
\text { significantly } \\
\text { higher in } \\
\text { participants on } \\
\text { contraceptive } \\
\text { when compared } \\
\text { with the control } \\
\text { group. Mn and } \mathrm{Pb} \\
\text { levels were similar } \\
\text { in participants and } \\
\text { control groups. }\end{array}$ \\
\hline (13) & $\begin{array}{l}\text { Random } \\
\text { ized, } \\
\text { triple- } \\
\text { blinded, } \\
\text { controll } \\
\text { ed }\end{array}$ & $\begin{array}{l}30 \mu \mathrm{g} \\
\text { norgestrel } \\
\text { and } 30 \mu \mathrm{g} \\
\mathrm{EE}+ \\
150 \mathrm{mg} \\
\text { vitamin } \mathrm{B}_{6} \\
30 \mu \mathrm{g} \\
\text { norgestrel } \\
\text { and } 30 \mu \mathrm{g} \\
\text { ethinyl } \\
\text { estradiol + } \\
\text { placebo } \\
30 \text { days }\end{array}$ & $\begin{array}{l}\mathrm{N}^{\circ}=124 \\
\text { Treatment:62 } \\
\text { Placebo: } 62\end{array}$ & $\begin{array}{l}\text { Women } \\
\text { aged 18- } \\
\text { 40, in good } \\
\text { general } \\
\text { health; } \\
\text { previous } \\
\text { users or } \\
\text { new } \\
\text { acceptors } \\
\text { of OC, } \\
\text { with } \\
\text { symptoms, } \\
\text { such as } \\
\text { nausea, } \\
\text { headache, } \\
\text { vomiting, } \\
\text { dizziness, } \\
\text { depression, } \\
\text { and/or } \\
\text { irritability, } \\
\text { not } \\
\text { explained } \\
\text { by any } \\
\text { specific } \\
\text { pathology } \\
\text { and likely } \\
\text { to be OC } \\
\text { side } \\
\text { effects. }\end{array}$ & $\begin{array}{l}\text { Contraindica } \\
\text { tions for } \\
\text { steroidal } \\
\text { contraceptiv } \\
\text { e use; the } \\
\text { use of } \\
\text { prescribed } \\
\text { medications } \\
\text { to treat OC } \\
\text { side effects; } \\
\text { and having a } \\
\text { pre-existing } \\
\text { neuropathy } \\
\text { or other } \\
\text { symptoms } \\
\text { that could be } \\
\text { confused } \\
\text { with } \\
\text { possible } \\
\text { vitamin B, } \\
\text { toxicity. }\end{array}$ & $\begin{array}{l}\text { Severity of } \\
\text { nausea, } \\
\text { headache, } \\
\text { vomiting, } \\
\text { dizziness, } \\
\text { depression, and } \\
\text { irritability } \\
\text { measured in a } \\
\text { quantitative } \\
\text { scale. }\end{array}$ & $\begin{array}{l}\text { From admission to } \\
\text { follow-up, there } \\
\text { was a decrease in } \\
\text { the severity of all } \\
\text { symptoms in both } \\
\text { groups. There was } \\
\text { no statistically } \\
\text { significant } \\
\text { difference in the } \\
\text { reductions found } \\
\text { in the vitamin } \mathrm{B}_{6} \text {, } \\
\text { and the placebo } \\
\text { groups, although } \\
\text { reductions in the } \\
\text { severity of } \\
\text { headache and } \\
\text { dizziness were } \\
\text { greater in the } \mathrm{B}_{6} \text {, } \\
\text { group. }\end{array}$ \\
\hline
\end{tabular}




\begin{tabular}{|c|c|c|c|c|c|c|c|}
\hline (12) & $\begin{array}{l}\text { Random } \\
\text { ized, } \\
\text { double- } \\
\text { blind, } \\
\text { active- } \\
\text { controll } \\
\text { ed, } \\
\text { parallel- } \\
\text { group }\end{array}$ & $\begin{array}{l}\text { EE/drsp+le } \\
\text { vomefolate } \\
\text { calcium: } \\
20 \mathrm{mcg} / 3 \mathrm{mg} \\
/ 0.451 \mathrm{mg} \\
\text { EE/drsp+pl } \\
\text { acebo: } \\
20 \mathrm{mcg} / 3 \mathrm{mg} \\
24 \text { weeks }\end{array}$ & $\begin{array}{l}\mathrm{N}^{\circ}=572 \\
\text { Treatment: } 285 \\
\text { Placebo:94 }\end{array}$ & $\begin{array}{l}\text { Healthy } \\
\text { female } \\
\text { volunteers } \\
\text { aged } 18- \\
40 \text { years } \\
\text { requesting } \\
\text { OC . } \\
\text { Normal or } \\
\text { non- } \\
\text { suspicious } \\
\text { cervical } \\
\text { smear at } \\
\text { screening } \\
\text { or within } 6 \\
\text { months } \\
\text { prior to } \\
\text { screening.. }\end{array}$ & $\begin{array}{l}\text { Pregnancy, } \\
\text { lactation, } \\
\text { abortion; } \\
\text { BMI>35; } \\
\text { hypersensiti } \\
\text { vity to any } \\
\text { of the study } \\
\text { drug } \\
\text { ingredients; } \\
\text { any disease } \\
\text { or condition } \\
\text { that could } \\
\text { compromise } \\
\text { the function } \\
\text { of body } \\
\text { systems or } \\
\text { affect the } \\
\text { pharmacokin } \\
\text { etics of the } \\
\text { study } \\
\text { medication; } \\
\text { current or } \\
\text { history of } \\
\text { clinically } \\
\text { significant } \\
\text { depression, } \\
\text { alcohol or } \\
\text { drug abuse; } \\
\text { treatment } \\
\text { with } \\
\text { prohibited } \\
\text { concomitant } \\
\text { medications; } \\
\text { less than } 6 \\
\text { menstrual } \\
\text { cycles since } \\
\text { intramuscula } \\
\text { r depot } \\
\text { contraceptio } \\
\text { n at } \\
\text { screening } \\
\text { visit; less } \\
\text { than one } \\
\text { menstrual } \\
\text { cycle since } \\
\text { removal of } \\
\text { hormone } \\
\text { purit; } \\
\text { expected } \\
\text { imajor } \\
\text { immining oring the } \\
\text { study period. }\end{array}$ & $\begin{array}{l}\mathrm{RBC} \text { and } \\
\text { plasma folate } \\
\text { levels }\end{array}$ & $\begin{array}{l}\text { Increases in mean } \\
\text { RBC and plasma } \\
\text { folate levels were } \\
\text { observed in } \\
\text { women who } \\
\text { received } \\
\text { EE/drsp/levomefol } \\
\text { ate calcium. } \\
\text { Marginal } \\
\text { fluctuations were } \\
\text { observed with } \\
\text { EE/drsp. }\end{array}$ \\
\hline
\end{tabular}




\begin{tabular}{|c|c|c|c|c|c|c|c|}
\hline (10) & $\begin{array}{l}\text { 4-cell } \\
\text { randomi } \\
\text { zed, } \\
\text { blind }\end{array}$ & $\begin{array}{l}\text { Norethindr } \\
\text { one+EE } 1 \\
\text { mg/0.035 } \\
\text { mg } \\
\text { + Daily } \\
\text { multi- } \\
\text { vitamin* } \\
\text { Norethindr } \\
\text { one+EE } 1 \\
\text { mg/0.035 } \\
\text { mg } \\
+ \text { Placebo } \\
\text { Norethindr } \\
\text { one+EE } \\
0.5 \\
\text { mg/0.035m } \\
\text { g } \\
+ \text { Daily } \\
\text { multi- } \\
\text { vitamin** }\end{array}$ & $\begin{array}{l}\mathrm{N}^{\circ} \\
\text { OC+vitamins= } \\
1288 \\
\mathrm{~N}^{\circ} \\
\text { OC+placebo= } \\
1363\end{array}$ & $\begin{array}{l}\text { Not } \\
\text { described }\end{array}$ & $\begin{array}{l}\text { Not } \\
\text { described }\end{array}$ & $\begin{array}{l}\text { Methodology of } \\
\text { Potter * }\end{array}$ & $\begin{array}{l}\text { Despite no } \\
\text { substantial } \\
\text { differences, most } \\
\text { of the side effects } \\
\text { in the multi- } \\
\text { vitamin group } \\
\text { were decreased }\end{array}$ \\
\hline
\end{tabular}

OC: oral contraceptives; EE: Ethinyl Estradiol; IUD: uterine device; BMI: body mass index; Zn: zinc; Cu: copper; Mn: manganese, Fe: iron; Se: selenium; Cd: cadmium; Pb: lead; Mg: magnesium; P: phosphorus; Ca: calcium, RBC: red blood cells; Kg: kilogram; h: height.

* = Potter R.G., in Family Planning in Taiwan (R. Freedman and J.Y. Takeshita, eds.) Princeton University Press, Princeton, 1969; 458483

** $=1.4 \mathrm{mg}$ of vitamin $\mathrm{B}_{1}, 1.7 \mathrm{mg}$ of vitamin $\mathrm{B}_{2}, 10 \mathrm{mg}$ of vitamin $\mathrm{B} 6,4 \mathrm{mcg}$ of vitamin $\mathrm{B}_{12}, 0.8 \mathrm{mg}$ of folate, $60 \mathrm{mg}$ of vitamin $\mathrm{C}$ and $16 \mathrm{mg}$ of niacin.

In addition, using the Daly model, ${ }^{14}$ NTDs risk reduction defined as a decrement in RBD folate levels from baseline to week 24 was evaluated as secondary variable. In the EE/drsp/levomefolate calcium group, a mean NTD risk reduction of 0.51 per 1000 births (corresponding to an estimated mean relative risk reduction of $37 \%$ ) was calculated compared to a mean of 0.03 per 1000 births in the EE/drsp group.

Incidence and drop out due to adverse reactions were similar for both groups: upper respiratory tract infections and low-density lipoprotein increase were the most frequently reported events.

The study of Villegas et al. ${ }^{13}$ was a randomized, tripleblinded controlled trial, conducted to evaluate the effects of vitamin B6 on the severity of the side effects of a lowdose combined OC (30 $\mu \mathrm{g}$ norgestrel and $30 \mu \mathrm{g}$ EE).

A total of 124 women were enrolled into the study and divided in two treatment groups (OC plus vitamin B6 and OC plus placebo). The treatment was performed for 30 days. The baseline characteristics between the two groups were similar except for headache: a higher proportion of women in placebo group reported moderate to severe headache at admission than in the vitamin B6 group ( $\mathrm{p}$ $<0.05)$.

From enrolment to the follow-up visits (1-3 months), severity of side effects was measured using a quantitative scale ranging 0 to 3 . Women in the vitamin B6 group reported a decreased severity of the OC side effects, 
mainly headache and dizziness, compared to the placebo group, despite no statistically difference was reported.

The study of Sriani ${ }^{10}$ was a 4 -cell randomized trial versus placebo conducted in 3 diverse sites in Sri Lanka to evaluate the impact of daily vitamin supplement, in preventing OC side effects.

The composition of the vitamin complex was: $1.4 \mathrm{mg}$ of vitamin $B_{1}, 1.7 \mathrm{mg}$ of vitamin $B_{2}, 10 \mathrm{mg}$ of vitamin $B_{6}$, $4 \mathrm{mcg}$ of vitamin $B_{12}, 0.8 \mathrm{mg}$ of folate, $60 \mathrm{mg}$ of vitamin $\mathrm{C}$ and $16 \mathrm{mg}$ of niacin.

The OC used were: norethindrone-EE (1 mg/0.035 mg) plus daily multi-vitamin or placebo, norethindrone-EE $(0.5 \mathrm{mg} / 0.035 \mathrm{mg})$ plus daily multi-vitamin or placebo.

The trial was conducted in 3 diverse sites: an urban area and two different rural areas. The first follow-up was scheduled 1 month after admission to the study. Further assessments were scheduled at 2-3 month intervals for 12 months.

Results demonstrated that in the urban area there was a lower frequency of most side effects, but this trend was not consistent and in most cases not statistically significant. No significant differences were found in the rural areas. Despite no substantial differences, most of the side effects in the multi-vitamin group were decreased.

Only one RCT focused on serum trace elements. ${ }^{11}$ In this cross-sectional randomized trial, Akinloye et al. performed a study analysing blood samples collected from 150 women of child-bearing age. One hundred of them were on different contraceptive methods (50 OC, 25 injectable and 25 intra-uterine device). Fifty noncontraceptive users served as control.
Serum zinc, copper, manganese, iron, selenium, cadmium, phosphorus, calcium, lead and magnesium levels were analysed. Except manganese and lead, results showed a significant difference between OC users and controls of all the above mentioned trace elements.

In addition, OC group was separately compared with injectable and intra uterine device (IUD) users, while women on injectables were compared with intra-uterine device users.

Iron levels showed significant differences in all comparison groups. On the contrary, no significant differences have been reported on manganese and lead levels.

Cadmium levels showed a significant difference only in control versus IUD group.

Copper showed significant differences in all the groups except in OC versus injectables and similarly, magnesium levels did not show significant difference only in the control group versus injectables.

Zinc and selenium levels showed significant difference between all the groups but no significant difference was reported between the IUD users versus control and the OC users versus injectables.

Finally, calcium and phosphorus levels move on opposite directions, with an increase of serum calcium levels and a decrease of serum phosphorus levels in women on contraceptives.

The comparative difference of all the analysed data is resumed in Table 2.

Table 2: Comparative differences between contraceptive users groups, and between contraceptive and control groups, using Student " $t$ " test ( $p$ values set at $p<0.05)$.

\begin{tabular}{|llllllll|} 
Parameter & $\begin{array}{l}\text { Contraceptive } \\
\text { vs. } \\
\text { control }\end{array}$ & $\begin{array}{l}\text { Control } \\
\text { vs. } \\
\text { OC }\end{array}$ & $\begin{array}{l}\text { Control } \\
\text { vs. } \\
\text { injectables }\end{array}$ & $\begin{array}{l}\text { Control } \\
\text { vs. } \\
\text { IUD }\end{array}$ & $\begin{array}{l}\text { OC } \\
\text { vs. } \\
\text { injectables }\end{array}$ & $\begin{array}{l}\text { OC } \\
\text { vs. } \\
\text { IUD }\end{array}$ & $\begin{array}{l}\text { Injectables } \\
\text { vs. } \\
\text { IUD }\end{array}$ \\
\hline Zinc & $\downarrow 0.001$ & 0.000 & 0.000 & NS & NS & 0.000 & 0.000 \\
\hline Copper & $\uparrow 0.001$ & 0.000 & 0.000 & 0.000 & NS & 0.000 & 0.000 \\
\hline Manganese & NS & NS & NS & NS & NS & NS & NS \\
\hline Iron & $\uparrow 0.001$ & 0.000 & 0.000 & 0.000 & 0.000 & 0.000 & 0.000 \\
\hline Selenium & $\downarrow 0.001$ & 0.000 & 0.000 & NS & NS & 0.000 & 0.000 \\
\hline Cadmium & $\uparrow 0.05$ & NS & NS & 0.002 & NS & NS & NS \\
\hline Phosphorus & $\downarrow 0.001$ & 0.000 & NS & NS & 0.000 & 0.000 & NS \\
\hline Calcium & $\uparrow 0.001$ & 0.000 & NS & NS & 0.000 & 0.000 & NS \\
\hline Lead & NS & NS & NS & NS & NS & NS & NS \\
\hline Magnesium & $\downarrow 0.001$ & 0.000 & NS & 0.003 & 0.000 & 0.000 & 0.022 \\
\hline
\end{tabular}

Adapted by Akinloye et al. ${ }^{11}$

$\mathrm{NS}=$ not significant

$\uparrow=$ increment

$\downarrow=$ reduction 


\section{DISCUSSION}

Despite a relatively high number of reports concerning the effects of OC on metabolic processes and serum trace element profiles, only a few of them had been designed as RCTs.

This review analyzed three placebo-controlled trials that described the effects of different supplements associated with OC use. ${ }^{10,12,13}$ In some of them ${ }^{13}$ dietary supplements reduced adverse symptoms correlated with OC, namely as headache and dizziness. One trial ${ }^{12}$ reported an improvement of RBC and plasma folate levels associated with vitamin supplements. Finally, another trial $^{11}$ reported a decrease in the serum concentration of zinc, selenium, phosphorus and magnesium selectively in OC users.

Our systematic review has some limitations, i.e. the different outcomes are reported with different statistical approach and they cannot be summarized in a metaanalysis. This reduces the possibility that conclusion reached in the single trial could be widespread. Nevertheless, bearing the above limitations in mind, this survey allows some considerations.

\section{Folate status}

Folate deficiency has been associated with a number of clinical conditions, including neural tube defects (NTDs) ${ }^{15}$ a leading cause of morbidity and mortality in neonates. ${ }^{16}$ Currently, folic acid supplementation guidelines issued by the US Preventative Services Task Force recommend all women of childbearing age a daily supplementation of $0.400-0.800 \mathrm{mg}$ of folic acid. In particular, this supplementation has to be commenced at least one month before conception and continued during the first two-three months of pregnancy. ${ }^{17}$

Early observational studies in OC users conducted in the 1960s led to the hypothesis that the use of synthetic hormones may negatively influence folate status. ${ }^{18,19}$ Subsequently, multiple studies on healthy women were performed: in all these cases, the dietary intake has been judged from adequate to good. ${ }^{7,20-22}$

Some Authors suggested that the absorption of naturallyoccurring food folate may be impaired in women using OC. ${ }^{23}$ It was further reported that absorption of the polyglutamyl folate form is reduced by about $50 \%$ in OC users versus non-users with no differences detected in the absorption of monoglutamyl folate. It was hypothesized that OC may impair the enzymatic cleavage by the intestinal folate conjugated enzyme required for polyglutamyl folate absorption. An additional proposed mechanism for impaired folate status is that OC may increase the clearance of folate from blood, ${ }^{24}$ possibly as a result of changes in liver enzymes or renal folatebinding proteins involved in reabsorption in the kidney. ${ }^{25}$
Other investigators proposed that OC use may impair folate metabolism via increased activity of microsomal enzymes requiring folate. In addition, there have been several early reports of increased serum, ${ }^{26}$ and leukocyte folate binders in OC users. ${ }^{27,28}$ It should be considered that the hormonal content of OCs was much higher in the 1960 s and 1970s when these studies were carried outraising the question of whether conclusions regarding the effect of OC use on folate status can still be extrapolated.

Anyway, the results obtained from the RCT included in this review ${ }^{12}$ confirm the findings of previous trials reporting that the levomefolate calcium intake increases both RBC and plasma folate levels. ${ }^{29}$ Furthermore, since it is recognized that only approximately $20 \%{ }^{4}$ of women in reproductive age consume the recommended intake of folic acid to reduce NTD risk, it will be important to plan supplementation in categories of women at higher risk such as OC users.

However, the decreases in the prevalence of NTDs have been reported since folic acid fortification of United States grain products began. It is not known whether folic acid plays a role in reducing the severity of occurring NTDs. Kirk et al. have carried out a study in which show that infants with spina bifida experienced a significantly improved first-year survival rate of $92.1 \%$ during the period of mandatory folic acid fortification. Infants with encephalocele had a statistically non-significant increase in survival rates, i.e., $79.1 \%$ with folic acid fortification, compared with $75.7 \%$ for earlier births. Folic acid may play a role in reducing the severity of NTDs in addition to preventing the occurrence of NTDs. This phenomenon contributes to our understanding of the efficacy of folic acid. $^{30}$

\section{Vitamin $B_{6}$}

Vitamin $B_{6}$ is an essential micronutrient required in coenzyme form (pyridoxal 5'-phosphate, PLP) for over 100 enzymes involved in amino acid, lipid, and glucose metabolism.

Vitamin $\mathrm{B}_{6}$ deficiency has been associated with a number of clinical symptoms, including convulsions, abnormal electroencephalograms, ${ }^{31,32}$ and may compromise health of the mother increasing the risk of complications during pregnancy. $^{33}$

The use of vitamin B6 has been recommended as a treatment for morning sickness in early pregnancy as well as for the management of women with Premenstrual Syndrome. ${ }^{8}$ Uncontrolled studies reported that a 25-30 $\mathrm{mg}$ daily supplementation of vitamin $\mathrm{B}_{6}$ can reduce the incidence of side effects among OC users. ${ }^{34}$

The association between vitamin $\mathrm{B}_{6}$ status and $\mathrm{OC}$ use was first made during the $60 \mathrm{~s}^{35}$ when increased urinary excretion of xanthurenic acid, kynurenine, and 3-OH- 
kynurenine was observed following a tryptophan load test. Several studies confirmed the finding of abnormal tryptophan metabolism in women using OCs, as well as its correction with mega doses of pyridoxine hydrochloride. $^{36,37}$ There is general consensus that estrogen disrupts tryptophan metabolism independently from vitamin B6 status, making the tryptophan load test a poor indicator of vitamin $\mathrm{B}_{6}$ status in OC users.

In a recent study performed in the United States ${ }^{38}$ plasma PLP concentration was found to be significantly reduced in $75 \%$ of low-dose OC users suggesting that higher intakes may be necessary to maintain adequate vitamin $\mathrm{B}_{6}$ status. These findings corroborate the previously reported data in which abnormalities of tryptophan metabolism in OC users were corrected by supplementation with mega-doses of vitamin B6. ${ }^{35,39}$

In the trial included in our systematic review ${ }^{13}$ there was a non-significant although appreciable effect of vitamin $\mathrm{B}_{6}$ supplementation on headache and dizziness related to OC use and higher proportions of women in the vitamin $\mathrm{B}_{6}$ group reported decreased OC-related side effect severity compared to the placebo group. Based on this small evidence further trials should be performed in order to define if supplementation with pyridoxine can reduce the incidence of side effects among OC users.

\section{Vitamin $B_{12}$}

Vitamin $\mathrm{B}_{12}$ (cobalamin) is an essential nutrient which acts as a cofactor for methionine synthase, accepting a methyl group from 5-methyltetrahydrofolate (5-Me-THF) in order to regenerate THF. As with inadequate maternal folate status, impaired maternal cobalamin status is an independent risk factor for NTDs. ${ }^{40}$

Methylmalonic acid (MMA) levels are often increased in early stages of vitamin $B_{12}$ deficiency, and Adams et al. ${ }^{40}$ suggested that cobalamin status may be related to the development of NTDs after finding that women with mid-trimester serum MMA levels $>90^{\text {th }}$ percentile had a 13-fold higher risk for having an NTD affected pregnancy.

Lower serum cobalamin concentrations have been associated with OC use, ${ }^{41-43}$ but the reduction in serum concentrations may not indicate a true cobalamin deficiency. This is supported by the lack of change in functional cobalamin indicators, such as homocysteine (Hcy) and MMA concentrations. Specifically, in some studies, no differences were detected in urinary MMA concentrations, ${ }^{44}$ plasma MMA concentrations, or plasma Hcy concentrations with $\mathrm{OC}$ use compared to controls. $^{43,45}$

However, in a study where dietary intake was controlled in addition to a number of other key variables, Riedel et $\mathrm{al}^{42}$ reported that low serum cobalamin concentrations were associated to $\mathrm{OC}$ use. In OC users, the median concentrations of both serum cobalamin and plasma holotranscobalamin (holoTC) were approximately $25 \%$ lower than in controls. Neither plasma concentrations of MMA nor Hcy concentrations were significantly higher in OC users versus non-users, although OC administration increased the risk of having serum MMA concentrations in the highest quartile. In OC users, both serum cobalamin and holo-TC were inversely correlated with plasma MMA and Hcy, while no such relationships were found in non-OC users. Since the mean concentrations of MMA and Hcy were unaffected by OC use, the investigators suggested OC use may result in a redistribution of cobalamin rather than a depletion of intracellular cobalamin. A potential explanation for the differences between studies is the diverse EE content of OCs.

In the trial included in our review ${ }^{10}$ findings show a negative influence of $\mathrm{OC}$ on the vitamin $\mathrm{B}_{12}$ status. This small evidence supports the concept that vitamin supplements could be helpful in OC users although these findings are not easily transferred to other populations.

\section{Serum trace elements}

Several studies have shown that in women under OC, concentrations of serum trace elements have been altered, although the magnitude of alteration is variable. Changes in the tissue level or bioavailability of such elements could play a significant role in health as well as in the pathogenesis of some disorder. ${ }^{1,46,47}$

Akinloye et al. ${ }^{11}$ confirmed these data, reporting a significant reduction in the levels of some trace elements in women on different contraceptive methods, and especially in the OC users, when compared with non-OC users. In detail, a significant decrease in the serum concentration of zinc, selenium, phosphorus and magnesium was described while a significant increase in serum level for copper, iron, cadmium was observed.

A recent case-control study ${ }^{48}$ was conducted to ascertain the influence of OC on serum zinc and selenium in OC users. The concentration of those elements was determined in 50 healthy women with normal menstrual cycles as a control group and 50 women taking low-dose OC for a minimum of 3 cycles. Use of OC resulted in a significant decrease mainly in serum zinc levels. These results were confirmed by the RCT analysed in this review. ${ }^{11}$

In the same trial, ${ }^{48}$ a significant reduction in the serum phosphorus levels and a significant increase in the serum calcium levels in women on OC respect to women on injectable contraceptives was described. These data are confirmed in our RCT. These findings are correlated to the fact that calcium and phosphate move in opposite directions therefore significantly elevated serum calcium level is reciprocated by a significantly reduced serum inorganic phosphate level. 
A significantly decreased in serum magnesium levels in OC users was found confirming the hypothesis that the OC play an important function in the absorption and metabolism of this element. ${ }^{49}$

Increased serum copper and iron levels were observed in particularly in women on IUD. The most likely hypothesis suggest that increased level of copper in contraceptives users may be related to a saturation of ceruloplasmin or in a plasma level reduction. ${ }^{2,50}$ Also the increased levels of iron may be associated with the decreased menstrual blood flow which usually occurs in these subjects. $^{51}$ No significant variation is described about serum cadmium levels in OC users.

In conclusion, these findings demonstrated an alteration in the levels of some vitamins serum trace elements in women taking OCs. These effects worsen with long-term consumption. A supplementation with the above compounds could be useful in OC users, in order to reduce possible side effects.

\section{Funding: No funding sources}

Conflict of interest: None declared

Ethical approval: Not required

\section{REFERENCES}

1. Theuer RC. Effect of Oral Contraceptive Agents on Vitamin and Mineral Needs: A Review. J Reprod Med. 1972;8:13-9.

2. Berg G, Kohlmeier L, Brenner H. Effect of Oral Contraceptive Progestins on Serum Copper Concentration. Eur J Clin Nutr. 1998;52:711-5.

3. Ghayour-Mobarhan M, Taylor A, New SA, Lamb DJ, Ferns GA. Determinants of Serum Copper, Zinc and Selenium in Healthy Subjects. Ann Clin Biochem. 2005;42:364-75.

4. Tamura T, Picciano MF. Folate and Human Reproduction. Am J Clin Nutr 2006;83: 993-1016.

5. Prevention of Neural Tube Defects: Results of the Medical Research Council Vitamin Study. Mrc Vitamin Study Research Group. Lancet. 1991;338:131-7.

6. Shojania AM, Hornady G, Barnes PH. Oral contraceptives and serum-folate level. Lancet. 1968;1:1376-7.

7. Prasad AS, Oberleas D, Moghissi KS, Stryker JC, Lei KY. Effect of Oral Contraceptive Agents on Nutrients: Ii. Vitamins. Am J Clin Nutr. 1975;28:385-91.

8. Wilson SM, Bivins BN, Russell KA, Bailey LB. Oral Contraceptive Use: Impact on Folate, Vitamin B(6), and Vitamin B(1)(2) Status. Nutr Rev. 2011;69:57283.

9. Moher D, Cook DJ, Eastwood S, Olkin I, Rennie D, Stroup DF. Improving the Quality of Reports of Meta-Analyses of Randomised Controlled Trials: The Quorom Statement. Quality of Reporting of Meta-Analyses. Lancet. 1999;354:1896-900.
10. Basnayake S, de Silva SV, Miller PC, Rogers S. A Trial of Daily Vitamin Supplementation as a Means of Reducing Oral Contraceptive Side Effects and Discontinuation in Sri Lanka. Contraception. 1983;27:465-72.

11. Akinloye O, Adebayo TO, Oguntibeju OO, Oparinde DP, Ogunyemi EO. Effects of Contraceptives on Serum Trace Elements, Calcium and Phosphorus Levels. West Indian Med. J 2011;60:308-15.

12. Bart S, Sr., Marr J, Diefenbach K, Trummer D, Sampson-Landers C. Folate Status and Homocysteine Levels During a 24-Week Oral Administration of a Folate-Containing Oral Contraceptive: A Randomized, Double-Blind, Active-Controlled, Parallel-Group, Us-Based Multicenter Study. Contraception. 2012;85:42-50.

13. Villegas-Salas E, Ponce de Leon R, Juarez-Perez MA, Grubb GS. Effect of Vitamin B6 on the Side Effects of a Low-Dose Combined Oral Contraceptive. Contraception. 1997;55: 245-8.

14. Daly LE, Kirke PN, Molloy A, Weir DG, Scott JM. Folate Levels and Neural Tube Defects. Implications for Prevention. JAMA. 1995;274:1698-702.

15. Botto LD, Moore CA, Khoury MJ, Erickson JD. Neural-Tube Defects. N Engl J Med. 1999;341:150919.

16. Northrup H, Volcik KA. Spina Bifida and Other Neural Tube Defects. Curr Probl Pediatr. 2000;30:313-32.

17. Holmes RP. Megaloblastic Anemia Precipitated by the Use of Oral Contraceptive. A Case Report. N C Med J. 1970;31:17-8.

18. Paton A. Oral Contraceptives and Folate Deficiency. Lancet. 1969;1:418.

19. Smith JL, Goldsmith GA, Lawrence JD. Effects of Oral Contraceptive Steroids on Vitamin and Lipid Levels in Serum. Am J Clin Nutr. 1975;28:371-6.

20. Mooij PN, Thomas CM, Doesburg WH, Eskes TK. Multivitamin Supplementation in Oral Contraceptive Users. Contraception. 1991;44:277-88.

21. Prasad AS, Lei KY, Moghissi KS, Stryker JC, Oberleas D. Effect of Oral Contraceptives on Nutrients. Iii. Vitamins $\mathrm{B}_{6}, \mathrm{~B}_{12}$, and Folic Acid. Am J Obstet Gynecol. 1976;125:1063-9.

22. Davis RE, Smith BK. Pyridoxal, Vitamin $B_{12}$ and Folate Metabolism in Women Taking Oral Contraceptive Agents. S Afr Med J. 1974;48:193740.

23. Stephens ME, Craft J, Peters TJ, Hoffbrand AV. Oral Contraceptives and Folate Metabolism. Clin Sci. 1972;42:405-14.

24. Da Costa M, Rothenberg SP. Appearance of a Folate Binder in Leukocytes and Serum of Women Who Are Pregnant or Taking Oral Contraceptives. J Lab Clin Med. 1974;83:207-14.

25. Corrocher R, Abramson RG, King VF, Schreiber C, Dikman S, Waxman S. Differential binding of folates by rat renal cortex brush border and basolateral membrane preparations. Proc Soc Exp Biol Med. 1985;178:73-84. 
26. Maxwell JD, Hunter J, Stewart DA, Ardeman S, Williams R. Folate Deficiency after Anticonvulsant Drugs: An Effect of Hepatic Enzyme Induction? Br Med J. 1972;1:297-9.

27. Areekul S, Panatampon P, Doungbarn J, Yamarat P, Vongyuthithum M. Serum Vitamin $B_{12}$, Serum and Red Cell Folates, Vitamin $\mathrm{B}_{12}$ and Folic Acid Binding Proteins in Women Taking Oral Contraceptives. Southeast Asian J Trop Med Public Health. 1977;8:480-5.

28. Venn BJ, Green TJ, Moser R, Mann JI. Comparison of the Effect of Low-Dose Supplementation with L5-Methyltetrahydrofolate or Folic Acid on Plasma Homocysteine: A Randomized Placebo-Controlled Study. Am J Clin Nutr. 2003;77:658-62.

29. Bol KA, Collins JS, Kirby RS; National Birth Defects Prevention Network. Survival of infants with neural tube defects in the presence of folic acid fortification. Pediatrics. 2006;117:803-13.

30. Pentieva K, McNulty H, Reichert R, Ward M, Strain JJ, McKillop DJ, et al. The Short-Term Bioavailabilities of [6s]-5-Methyltetrahydrofolate and Folic Acid Are Equivalent in Men. J Nutr. 2004;134:580-5.

31. Snyderman SE, Holt LE, Jr., Carretero R, Jacobs K. Pyridoxine Deficiency in the Human Infant. J Clin Nutr. 1953;1:200-7.

32. Sahakian V, Rouse D, Sipes S, Rose N, Niebyl J. Vitamin $\mathrm{B}_{6}$ Is Effective Therapy for Nausea and Vomiting of Pregnancy: A Randomized, DoubleBlind Placebo-Controlled Study. Obstet Gynecol. 1991;78:33-6.

33. Kleijnen J, Ter Riet G, Knipschild P. Vitamin $B_{6}$ in the Treatment of the Premenstrual Syndrome--a Review. Br J Obstet Gynaecol. 1990;97:847-52.

34. Aly HE, Donald EA, Simpson MH. Oral Contraceptives and Vitamin $\mathrm{B}_{6}$ Metabolism. Am J Clin Nutr. 1971;24:297-303.

35. Price JM, Thornton MJ, Mueller LM. Tryptophan Metabolism in Women Using Steroid Hormones for Ovulation Control. Am J Clin Nutr. 1967;20:452-6.

36. Luhby A, Reyniak J, Brin M, Sambour M, Brin H. Abnormal Vitamin $\mathrm{B}_{6}$ Metabolism in Menopausal Women Given Estrogenic Steroids and Its Correction by Pyridoxine. American Journal of Clinical Nutrition. 1973;26:468-69.

37. Bulbrook RD, Herian M, Tong D, Hayward JL, Swain MC, Wang DY. Effect of Steroidal Contraceptives on Levels of Plasma Androgen Sulphates and Cortisol. Lancet. 1973;1:628-31.

38. Luhby AL, Brin M, Gordon M, Davis P, Murphy M, Spiegel H. Vitamin B 6 Metabolism in Users of Oral Contraceptive Agents. I. Abnormal Urinary Xanthurenic Acid Excretion and Its Correction by Pyridoxine. Am J Clin Nutr. 1971;24:684-93.
39. Dror DK, Allen LH. Effect of Vitamin B12 Deficiency on Neurodevelopment in Infants: Current Knowledge and Possible Mechanisms. Nutr Rev. 2008;66:250-5.

40. Adams MJ Jr, Khoury MJ, Scanlon KS, Stevenson RE, Knight GJ, Haddow JE et al. Elevated Midtrimester Serum Methylmalonic Acid Levels as a Risk Factor for Neural Tube Defects. Teratology. 1995;51:311-7.

41. Pietarinen GJ, Leichter J, Pratt RF. Dietary Folate Intake and Concentration of Folate in Serum and Erythrocytes in Women Using Oral Contraceptives. Am J Clin Nutr. 1977;30:375-80.

42. Riedel B, Bjorke Monsen AL, Ueland PM, Schneede J. Effects of Oral Contraceptives and Hormone Replacement Therapy on Markers of Cobalamin Status. Clin Chem. 2005;51:778-81.

43. Shojania AM, Wylie B. The Effect of Oral Contraceptives on Vitamin B12 Metabolism. Am J Obstet Gynecol. 1979;135:129-34.

44. Gardyn J, Mittelman M, Zlotnik J, Sela BA, Cohen AM. Oral Contraceptives Can Cause Falsely Low Vitamin B(12) Levels. Acta Haematol. 2000;104:224.

45. Bush AI. The Metallobiology of Alzheimer's Disease. Trends Neurosci. 2003;26: 207-14.

46. Schrauzer GN. Selenium and Cancer: A Review. Bioinorg Chem. 1976;5:275-81.

47. Crews MG, Taper LJ, Ritchey SJ. Effects of Oral Contraceptive Agents on Copper and Zinc Balance in Young Women. Am J Clin Nutr. 1980;33:1940-5.

48. Hameed A, Majeed T, Rauf S, Ashraf M, Jalil MA, Nasrullah $M$ et al. Effect of Oral and Injectable Contraceptives on Serum Calcium, Magnesium and Phosphorus in Women. J Ayub Med Coll Abbottabad. 2001;13:24-5.

49. Blum M, Kitai E, Ariel Y, Schnierer M, Bograd H. Oral Contraceptive Lowers Serum Magnesium. Harefuah. 1991;121:363-4.

50. Ynsa MD, Ager FJ, Millan JC, Gomez-Zubelbia MA, Pinheiro T. Effect of Hormone Replacement Therapy on the Elemental Contents of Uterine Tissue. Biol Trace Elem Res. 2004;101:37-46.

51. Greig AJ, Palmer MA, Chepulis LM. Hormonal Contraceptive Practices in Young Australian Women $(</=25$ Years $)$ and Their Possible Impact on Menstrual Frequency and Iron Requirements. Sex Reprod Healthc. 2010;1:99-103.

DOI: $10.5455 / 2320-1770$. ijrcog20140301

Cite this article as: Dante G, Vaiarelli A,

Facchinetti F. Vitamin and mineral needs during the oral contraceptive therapy: a systematic review. Int J Reprod Contracept Obstet Gynecol 2014;3:110 . 